\title{
Development of a new method for the isolation of viable mesenchymal stem cells for transplantation in animal models
}

\author{
Vassiliki E. Kalodimou ${ }^{*}$, Marina Kontogiorgi ${ }^{2}$ and Apostolos Papalois ${ }^{2}$ \\ ${ }^{1}$ Department of Flow Cytometry-Research \& Regenerative Medicine “IASO” - Maternity Hospital / MedStem Services, Athens, Greece \\ ${ }^{2}$ Experimental - Research Center, ELPEN Pharmaceuticals, Athens, Greece
}

\begin{abstract}
Background: Recent reports have shown that mesenchymal stem cells (MSC's) could be used for transplantation in various animal models. Mesenchymal stem cells exhibit remarkable plasticity and harbor potential for use in therapeutic applications, such as lung fibrosis

Study design and method: The aim of this study was to isolate mesenchymal stem cells from rat bone marrow, count the actual MSC's numbers and their viability, using flow Cytometry, and infuse them on an experimental injured animal model.

We used magnetic beads (MACS) as a delivery system for novel mesenchymal stem cells (MSC's) isolated from rat bone marrow and the total number was counting using a Beckman Coulter FC 500 flow cytometer.

Results: Bone marrow samples from 60 Wistar rats, $>250 \mathrm{~g}$ and six weeks old, were used for the isolation of MSC's. All samples were stored at room temperature and processed immediately. The total number of MSC's was isolated and the absolute numbers of MSC's as well as the viability of each sample was determined using flow cytometry. We used tripan blue to distinguish the viable cells and the mesenchynmal cells for microscopic analysis as well.

Conclusion: We succeed to isolate MSC's from all 60 samples with a mean value of $1.14 \times 106$, while the number of unsorted bone marrow cells required for a transplant is $1.05 \times 106$ by bibliography. We found that the mean viability value of the samples was $77.6 \%$ suggesting good sample collection and processing conditions
\end{abstract}

\section{Introduction}

Similar to hematopoietic stem cells, mesenchymal stem cells (MSC's) are a type of stem cells derived from the bone marrow (BM). They were identified by Cohnheim in 1867 and were described by Friedenstein and colleagues. MSC's exhibit remarkable plasticity and harbor potential for use in therapeutic applications, such as fibrosis, cardiovasculogenesis treatments, arteriogenesis, and immunosuppression and they can also be used in tissue engineering and the correction of genetic disorders [1-4].

Mesenchymal stem cells, are defined as a self-renewing population of adherent, bone-marrow derived multipotent progenitor cells with the capacity to differentiate into several mesenchymal cell lineages $[5,6]$.

They have been isolated based on their ability to form adherent cell layers in culture and the concomitant lack of adherence of other cells in the bone marrow stroma such as hematopoietic stem cells, adipocytes and macrophages [7-9]. There has been great interest in these cells both because of their value as a model for studying the molecular basis of differentiation and because of their therapeutic potential for tissue repair, such as lung injury, and immune modulation [10,11].

We tried to establish an isolation of mesenchymal stem cells from rat bone marrow in order to infuse them in injured animal models.

We used Wistar rat's $\geq 250 \mathrm{~g}$ ( 10 weeks old), as a clinical model, to evaluate the effect of MSC's on transplantation in animal models.

\section{Materials and methods}

\section{Animal models}

Sixty adult male Wistar rats weighing 250 - 300g were obtained from "Demokritus" Research Center, Athens.

All experimental procedures described below were approved by the Animal Ethical Committee of the Veterinary Directorate of the Local Prefecture, according to the European Union Act and the Greek low PD 160 (A-64, May 1991). Also all animals received proper care in compliance with the "Principles of laboratory Animal Care" and the "Guide for the Care and Use of Laboratory Animals", prepared by the Academy of Science and published by the National Institute of Health.

Rats were acclimatized to our laboratory conditions for 1 week prior to use in experiments and housed individually in stainless steel cages at a constant temperature $\left(24^{\circ} \mathrm{C}\right)$ and a $12 \mathrm{~h}$ day/night cycle. Rats ate commercial rat chow and had water and libitum.

Correspondence to: Vasiliki E. Kalodimou, Director of Flow CytometryResearch and Regenerative Medicine Department, IASO-Maternity and Research Hospital, Kifisias Ave.37-39, 151 25, Marousi-Athens, Greece, Tel: 0030-210-6185203; E-mail: kalodimou@yahoo.gr

Key words: mesenchymal stem cells; flow cytomertry; magnetic beads; rat bone marrow

Received: July 15, 2016; Accepted: August 15, 2016; Published: August 18, 2016 
All rats were anesthetized with intramuscular administration of ketamine hydrochloride $(120 \mathrm{mg} / \mathrm{Kg}$ body weight-b.w.), midazolame (5 mg/Kg b.w.) and atropine sulphate (0,2 mg/Kg b.w.).

\section{Mesenchymal stem cells isolation}

Samples of 60 Wistar rats derived from bone marrow were obtained for the isolation of MSC's.

When working with anticoagulated peripheral blood or buffy coat, peripheral blood mononuclear cells (PBMCs) should be isolated by density gradient centrifugation using Ficoll-Paque Plus (GE Healthcare, 17-1440-2 / Greece).

Lymphocyte isolation using Ficoll-Paque Plus is based on methodology established through the extensive studies of Boyum. The separation media consists of a mixture of Ficol 400 and an iodinated density gradient medium such as sodium diatrizoate. To remove platelets after density gradient separations the cell pellet was resuspended in a buffer solution and centrifuged at $200 \mathrm{x}$ g for $10-15$ minutes at $20^{\circ} \mathrm{C}$.

In all 60samples the white blood cells (WBC) counts were obtained and the cell suspension was centrifuged at $300 \mathrm{x} g$ for 10 minutes. The supernatant was aspirated completely and the cell pellet was stained with the Cy5-conjugated antibody-CD29 (PE/Cy5 anti-mouse/rat CD29, BIOLEGEND, 102219/HM $\beta$ 1-1, Greece), according to the manufacturer's recommendations. The samples were then vortexed gently for a few seconds and incubate for 10 minutes in the dark in the refrigerator at $2-8^{\circ} \mathrm{C}$.

The cells were then washed with $2 \mathrm{~mL}$ of buffer per $10^{7}$ cells (was made up of rinsing solution and MACS BSA stock solution by $1 / 10$ [autoMACS Rinsing Solution 1450 mL, 130-091-222, Miltenyi Biotec, Greece \& MACS BSA stock solution 75 mL, 130-091-376, Miltenyi Biotec, Greece]), to remove unbound antibody and centrifuged at 300 $\mathrm{x} \mathrm{g}$ for 10 minutes. The supernatant was then aspirated completely and the cell pellet was resuspened in $80 \mu \mathrm{L}$ of buffer per $10^{7}$ total cells.

Then, we added $20 \mu \mathrm{L}$ of Anti-Cy5/Anti-Alexa Fluor 647 MicroBeads per $10^{7}$ total cells (Anti-Cy5/Anti-Alexa Fluor 647 MicroBeads $2 \mathrm{~mL}, 130-091-395$, Miltenyi Biotec, Greece). The cells were vortexed gently for a few seconds and incubate for 15 minutes in the refrigerator at $2-8^{\circ} \mathrm{C}$. After the 15 minutes had passed the cells were washed by adding $2 \mathrm{~mL}$ of buffer per $10^{7}$ cells and centrifuge at $300 \mathrm{x}$ $\mathrm{g}$ for 10 minutes. The supernatant was then aspirated completely and the cell pellet was resuspended up to $10^{8}$ cells in $500 \mu \mathrm{L}$ of buffer. The procedure was repeated for all 60 samples.

In order to make our hypothesis stronger and double confirm the expression of mesenchymal stem cells in our samples, we used the following antibodies as well : CD117 (c-kit, MicroBeads, 130092-924, Miltenyi Biotec, Greece), CD105 (MultiSort Kit, 130092-924, Miltenyi Biotec, Greece), for positive results and CD11b (MicroBeads,130-049-601, Miltenyi Biotec, Greece) and CD45 (MicroBeads, 130-052-301, Miltenyi Biotec, Greece) for negative results. All antibodies were used according to the manufacturer's recommendations.

We used tripan blue (tripan-blue solution, $5 \mathrm{mg} / \mathrm{ml}$ in saline, 03102-1B, Biological Industries, Germany), to distinguish the viable cells and the mesenchynmal cells for microscopic analysis as well.

\section{Magnetic separation}

We choose the 25 LS MACS separator columns (25 LS Columns,
130-042-401, Miltenyi Biotec, Greece) in order to get $10^{8}$ cells as the maximum number of labeled cells and $2 \times 10^{9}$ as the maximum number separators of total cells.

The column was placed in the magnetic field (MidiMACS Separator, 130-042-303, Miltenyi Biotec, Greece), and was prepared by rinsing through $3 \mathrm{~mL}$ of buffer. Then the cell suspension was applied onto the column.

We collected the unlabeled cells that passed through, and the column was washed with $3 \times 3 \mathrm{~mL}$ of buffer.

The total effluent was collected (this was the unlabeled cell fraction), and the washing step was repeated three times by adding buffer solution.

After the washing step was finished we removed the column and placed it on a $25 \mathrm{~mL}$ Falcon tube. A $5 \mathrm{~mL}$ buffer solution was pipette onto the column and the magnetically labeled cells were immediately flushed out by firmly pushing the plunger into the column.

The total volume of $5 \mathrm{~mL}$ MSC's were collected in the $50 \mathrm{~mL}$ Falcon tube (BD Biosciences, $50 \mathrm{~mL}$ Falcon tube, high-clarity, flat-seal screw cap, 352070, Greece), and was placed in ice before the infusion in our rat models (data not shown). We repeated the procedure for all 60 samples.

\section{Flow cytometry analysis}

Flow cytometry systems apply the principles of flow cytometry to analyze biological specimens in order to identify various cell populations determined by the specific monoclonal antibodies and fluorochromes used [34].

In the flow cytometer, particles are carried to the laser intercept in a fluid stream. Any suspended particle of cell from 0.2-150 micrometers in size is suitable for analysis [20].

The characteristic or parameters of each event are based on its light scattering and fluorescent properties

A Cytomics FC 500 manufactured by Beckman Coulter/Greece, with CXP software for the Cytomics FC 500 flow cytometry system version 2, 2 was used. We used $500 \mu \mathrm{L}$ from the total volume of 5 mL MSC's in order to count the total number of MSC's cells and the viability of those cells in the sample, using flow cytometry.

Sample analysis was typically completed within 10 minutes.

\section{Statistical analysis}

Data was expressed as mean +/-SD. Significant differences were determined by using Epi Info, Version 3.5.1. Statistical significance was set at $\mathrm{p}<0.05$ for multiple comparisons.

\section{Results}

At the moment it is not clear how to best characterize stem cells from rats, based upon the limited markers available and it is still not clear how many numbers of isolated stem cells are necessary for tissue repair or indeed which method is better for the transplantation of the cells [12-15].

To determine a suitable cell source and isolation method, we attempted to isolated rat MSC's from bone marrow using magnetic separation and stained with the Cy5-conjugated antibody-CD29, and validated the results by flow cytometry (Figure 1). 

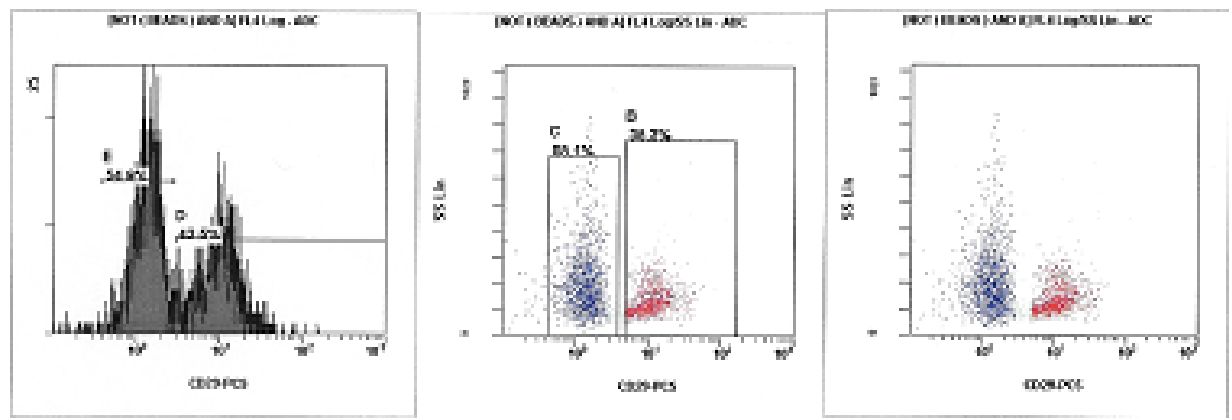

Figure 1. Mesenchymal Stem Cell isolation by Flow Cytometry, using Cy5-conjugated antibody-CD29.

Mesenchymal stem cells are defined as a self-renewing population of adherent, bone-marrow-derived multipotent progenitor cells with the capacity to differentiate into several mesenchymal cell lineages [16-18].

In defined in vitro assays, mesenchymal stem cells have been shown to readily differentiate into lineage-specific cells that form bone, cartilage, fat, tendon, and muscle tissues [19-21].

The multipotent potential of rat MSC's in vitro provides new avenues for cell-based therapy, and studies have demonstrated the use of 3-D scaffolds for tissue engineering using rat MSC's [22-24].

Bone marrow samples from $60 \mathrm{Wistar}$ rats, $>250 \mathrm{~g}$ and six weeks old, derived from bone marrow were used for the isolation of MSC's. All samples were stored at room temperature and processed immediately.

The total number of MSC's (Figure 2) was counted and the viability of each sample was determined using flow Cytometry (Figure 1).

We show that after the magnetic separation the mean number of MSC's was found to be $1.14 \times 10^{6}$ (mean +/-S.E.) while the number of unsorted bone marrow cells required was $1.05 \times 10^{6}$. (Table 1 and Figure 3)

The viability was found to be $77.6 \%$ (mean +/-S.E.), of the total cell population. (Table 1 and Figure 4)

Furthermore, we also attempted to look at the loss of MSC's counts in the samples over time (after 24 hours), and to assess whether progressive loss could lead to an insufficient amount of cells prior to transplantation.

In order to address this question, we took 14 duplicates samples. The first set of 14 were counted at day 0 , when they came to the lab, and the duplicate set of 14 were stored overnight in the refrigerator at $2-8^{\circ} \mathrm{C}$ and counted the next day, day 1 . All samples were from a Wistar rat model $>250 \mathrm{~g}$ and six weeks old (Table 2).

We observed a small drop in the number of MSC's in the set of samples that were stored overnight and their viability (\%) of the cells in all the samples, but these differences found to be not significant, $\mathrm{p}<0,0005$ for the MSC's absolute numbers, and significant, $\mathrm{p}>3,0319$ for the viability counts (Table 2 ).

We also observed that the number of WBC's counts in the rats seemed to play an important role as well as in the total actual number of MSC's, (Figure 5 and 6), therefore we also used 14 Wistar rats models $\geq 250 \mathrm{~g}$ and 10 weeks old in duplicates to investigate our hypothesis.

Our findings reveal that as the number of WBC's counts increased the actual number of MSC's, ( $p>3,3496)$, in the sample was greater than those with smaller amounts of WBC counts, $(p>2,2051)$. This

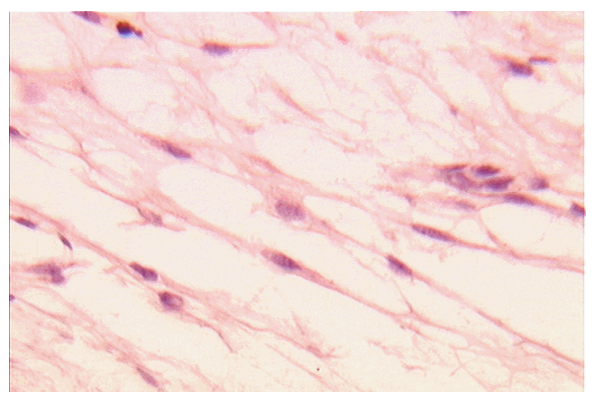

Figure 2. Rat Mesenchymal Stem Cells using tripan blue for distinguish the viable cell (x 400).

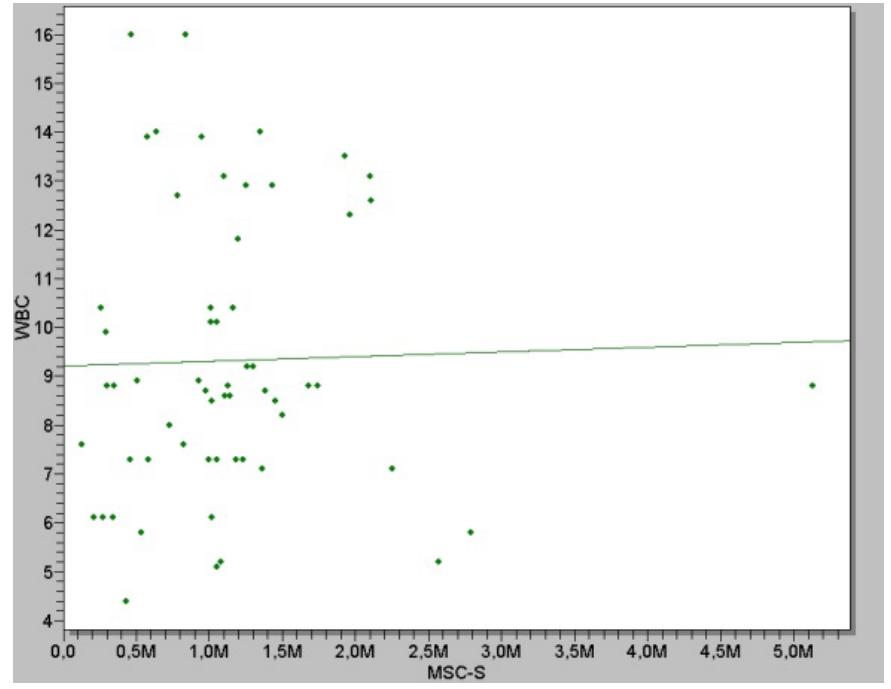

Figure 3. Scatter plot showing the correlation between WBC counts and MSC's values from rat bone marrow, as the WBC values increased, higher the MSC's values we get.

assumption need to be tested further.

\section{Discussion}

It has become apparent that the ability of stem cells to proliferate and differentiate to replace damaged cells and tissues is an important factor in determining outcome [8].

Stem cells can be an unlimited source of cells to enhance organ specific repair or replace lost tissue.

Recent reports have shown the capacity of mesenchymal stem cells to differentiate into several types of cells. As an example, administration of stem cells could initiate the repair of injured lung, but it is still not clear the required absolute number of stem cells that would need to be 
Table 1. Absolute counts of WBC counts, MSC's and Viability (\%), in 60 Wistar rat-bone marrow samples.

\begin{tabular}{|l|c|c|c|}
\hline \multicolumn{1}{|c|}{} & wbc & msc's & viability \% \\
\hline average & 9,293333333 & 1.143 .339 & 77,58333333 \\
\hline standard deviation & 2,858698689 & 789236,3531 & 6,528403825 \\
\hline median & 8,8 & 1.050 .000 & 78,5 \\
\hline mode & 8,8 & 1.050 .000 & 70 \\
\hline max & 16 & 5.130 .000 & 91 \\
\hline $\min$ & 4,4 & 127.000 & 61 \\
\hline
\end{tabular}

Table 2. Absolute counts of WBC counts, MSC's and Viability (\%), in the 14 Wistar rat-bone marrow samples at day 0 and at day 1 . Statistics analysis between the absolute number of MSC'S counts reveal a mean difference between Day 0 and Day 1, ranged from $0.82-1.23$ which is not significant $(\mathrm{p}<0.005)$, and between the viability values at, showed a $\mathrm{p}>3,0319$, which is significant.

\begin{tabular}{|l|c|c|c|c|c|c|}
\hline & wbc & may 0 & & & Day 1 & \\
\hline average & 9,95 & 1.178 .071 & 82,92857143 & 9,95 & 949.786 & 75,5 \\
\hline $\begin{array}{l}\text { standard } \\
\text { deviation }\end{array}$ & 3,079398 & 239186,9 & 4,196413958 & 3,079398 & 330910,9056 & 5,459642141 \\
\hline median & 8,85 & 1.135 .000 & 83 & 8,85 & 975.000 & 75 \\
\hline max & 16 & 1.740 .000 & 90 & 16 & 1.680 .000 & 84 \\
\hline min & 5,2 & 835.000 & 73 & 5,2 & 465.000 & 65 \\
\hline
\end{tabular}

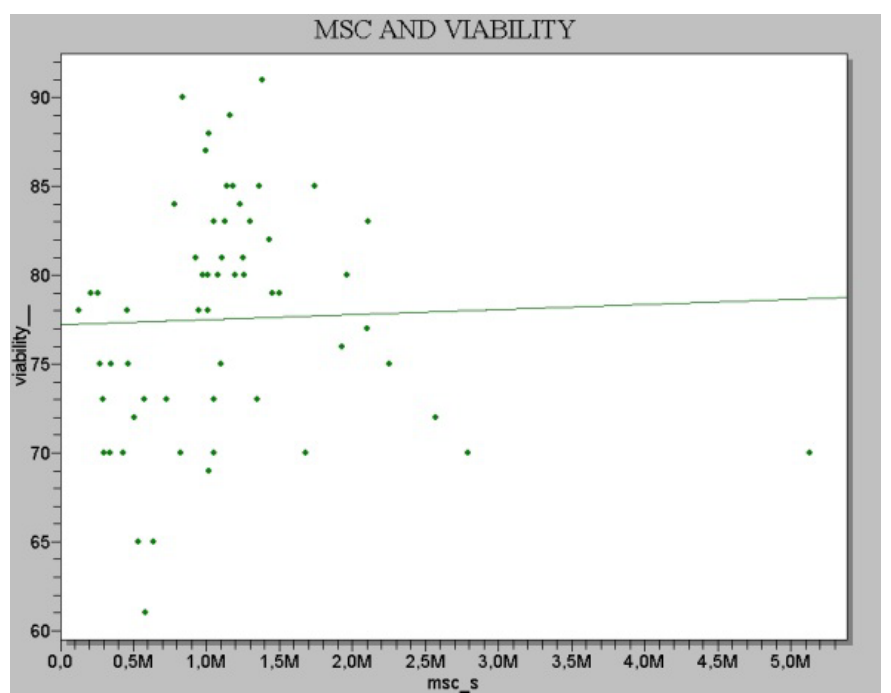

Figure 4. Scatter plot showing the correlation between Viability (\%) and MSC's values in rat bone marrow.

delivered to achieve effective tissue repair.

In the current study mesenchymal stem cells were isolated from the bone marrow of 60 Wistar rat models $\geq 250 \mathrm{~g}$ and 10 weeks old. We also tried to look at any limitations in the small number of WBC's counts at starting point, as well as the cell loss during time.

We succeed to isolate MSC's from all 60 samples with a mean value of $1.14 \times 10^{6}$ while the number of unsorted bone marrow cells required for a transplant is $1.05 \times 10^{6}$ by bibliography. We found that the mean viability value of the samples was $77.6 \%$ suggesting good sample collection and processing conditions.

In order to investigate the cell loss against time, 14 Wistar rats' $\geq$ $250 \mathrm{~g}$ and 10 weeks old were used in duplicates against time. The values of MSC's and viability (\%), were measured at day 0 , the day the marrow was delivered to the lab, and day 1 , after the samples were left inside the refrigerator at $2-8^{\circ} \mathrm{C}$ and counted the next day by flow cytometry.

Our findings revealed a small, $(\mathrm{p}<0,0005)$, decreased during time

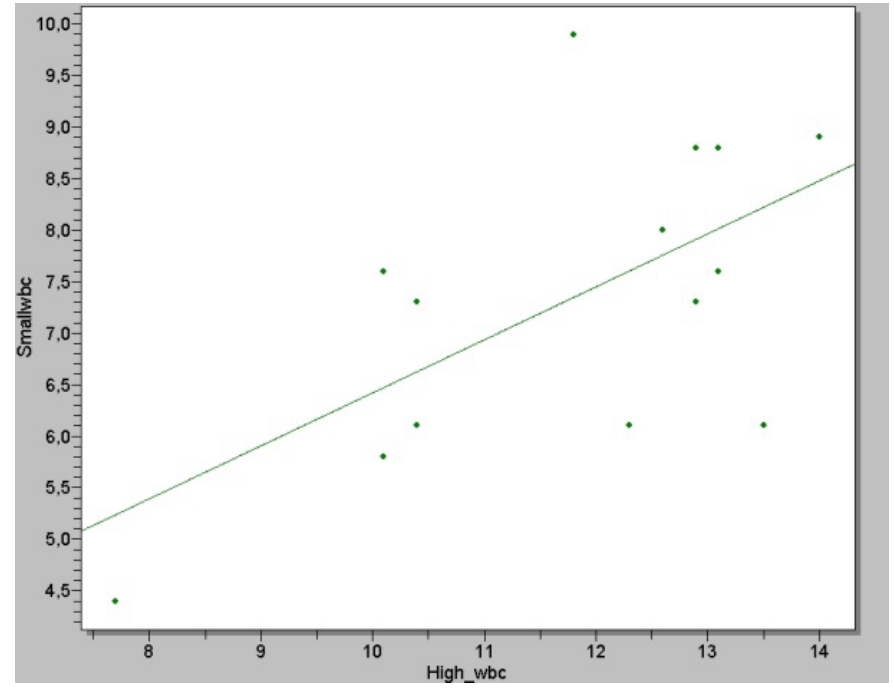

Figure 5. Scatter plot showing the correlation between high and small WBC counts in the 14 Wistar rat samples. The statistical analysis revealed a $\mathrm{p}$ value of 2,2051 , which is significant.

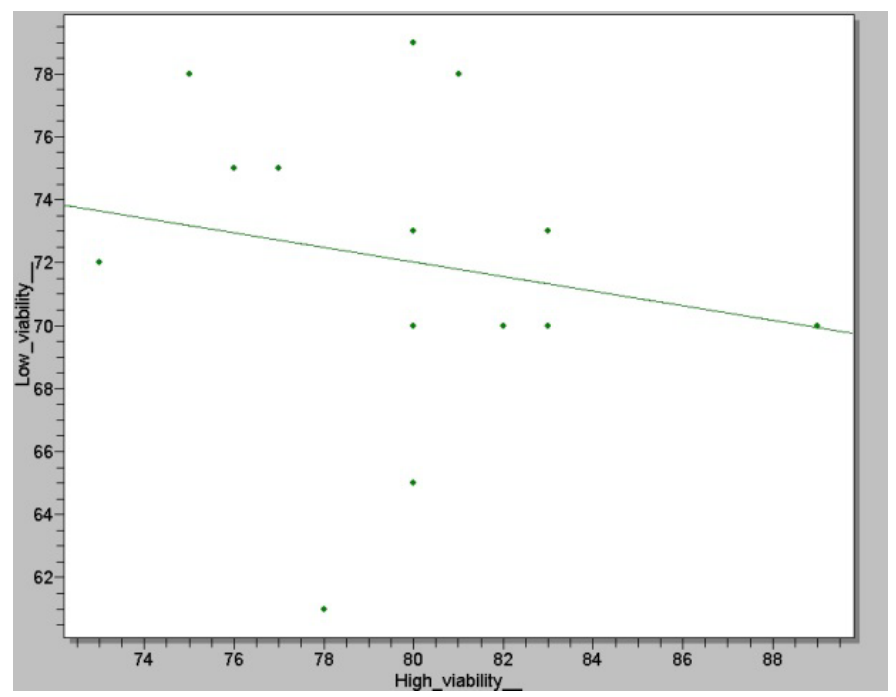

Figure 6. Scatter plot showing the correlation between high and small Viability (\%) values in the 14 Wistar rat samples. The statistical analysis revealed a $p$ value of 0,0005 , which is not significant.

in MSC's number but a large drop in the viability (\%) values, $(\mathrm{p}>3$, 0319), due to cell death and the sensitivity of the method used, this assumption need to be tested further.

To take our research a step further, we tried to find out if small WBC counts affects the absolute number of MSC's in the sample. 14 Wistar rats models $\geq 250 \mathrm{~g}$ and 10 weeks old were used in duplicates to investigate our hypothesis.

Our findings revealed a high correlation of samples with low WBC counts but very good collection volumes, ( $p>2,2051)$, with low counts of MSC's, ( $p>3,3496)$. Sample with low WBC counts tends to give a decreased number of MSC's as well as absolute counts of viability (\%). We can thus suggest that many parameters influence the WBC counts of collected bone marrow units, which directly affects the absolute number of MSC's. Such parameters could be the time prior to procedure, the small starting WBC's values, the rat model etc. This 
assumption need to be tested further.

Stem cell transplantation has many theoretical advantages. Organ failure and organ damages, is a major cause of death worldwide. Stem cell transplantation could be a very good alternative as a future solution.

MSC's have the ability of versatility, manageability, and the ability to proliferate for prolonged periods without undergoing transformation [25-27,35]. The pleiotropic immune-related properties of MSC's (low immunogenicity and lack of alloreactivity) have potential for achieving haematopoietic stem cell transplantation (HSCT) with a low incidence of GVHD (graft-versus-host disease) [28-30]. In addition, the low cost of maintaining mice and the detailed knowledge of mouse genetics [31,32], favour the utilization of murine MSC's (mMSC's) for extensive studies in the field of adult stem cell research $[33,34,36]$.

There is no doubt that the future of regenerative medicine depends strongly on the advancement of research in cellular and molecular biology and genetics, and also close interdisciplinary collaborations among scientists and clinicians should be established and potentiated.

Stem cells seem to have a great promise for use in regenerative medicine and cell therapy in the future.

\section{Conflict of interest}

All the authors declare that they have no conflicts of interest relevant to the manuscript submitted to Transfusion.

\section{References}

1. Armstrong RJ, Svendsen CN (2000) Neural stem cells: from cell biology to cell replacement. Cell Transplant 9: 139-152. [Crossref]

2. Awad HA, Butler DL, Boivin GP, Smith FN, Malaviya P, et al. (1999) Autologous mesenchymal stem cell-mediated repair of tendon. Tissue Eng 5: 267-277. [Crossref]

3. Barry FP, Murphy JM (2004) Mesenchymal stem cells: clinical applications and biological characterization. Int J Biochem Cell Biol 36: 568-584. [Crossref]

4. Berardi AC, Wang A, Levine JD, Lopez P, Scadden DT (1995) Functional isolation and characterization of human hematopoietic stem cells. Science 267: 104-108. [Crossref]

5. Delorme B, Charbord P (2007) Culture and characterization of human bone marrow mesenchymal stem cells. Methods Mol Med 140: 67-81. [Crossref]

6. Chamberlain JR, Schwarze U, Wang PR, Hirata RK, Hankenson KD, et al. (2004) Gene targeting in stem cells from individuals with osteogenesis imperfecta. Science 303: 1198-1201. [Crossref]

7. Chen X, Armstrong MA, Li G (2006) Mesenchymal stem cells in immunoregulation. Immunol Cell Biol 84: 413-421. [Crossref]

8. Conget PA, Minguell JJ (1999) Phenotypical and functional properties of human bone marrow mesenchymal progenitor cells. J Cell Physiol 181: 67-73. [Crossref]

9. Dennis JE, Merriam A, Awadallah A, Yoo JU, Johnstone B, et al. (1999) A quadripotential mesenchymal progenitor cell isolated from the marrow of an adult mouse. J Bone Miner Res 14: 700-709. [Crossref]

10. Devine SM, Bartholomew AM, Mahmud N, Nelson M, Patil S, Hardy W, Sturgeon C, Hewett T, Chung T, Stock W, Sher D, Weissman S, Ferrer K, Mosca J, Deans R, Moseley A, Hoffman R. Mesenchymal stem cells are capable of homing to the bone marrow of non-human primates following systemic infusion. Exp Hematol 29: 244-255

11. Devine SM, Cobbs C, Jennings M, Bartholomew A, Hoffman R (2003) Mesenchymal stem cells distribute to a wide range of tissues following systemic infusion into nonhuman primates. Blood 101: 2999-3001. [Crossref]

12. Djouad F, Plence P, Bony C, Tropel P, Apparailly F, et al. (2003) Immunosuppressive effect of mesenchymal stem cells favors tumor growth in allogeneic animals. Blood 102 : 3837-3844. [Crossref]

13. El-Badri NS (2006) The mesenchymal stem cell advantage. Stem Cells Dev 15: 473 474. [Crossref]

14. Gerson SL (1999) Mesenchymal stem cells: no longer second class marrow citizens. Nat Med 5: 262-264. [Crossref]
15. Gimble JM, Morgan C, Kelly K, Wu X, Dandapani V, (1995) Bone morphogenetic proteins inhibit adiposyte differentiation by bone marrow stromal cells. J Cell Biochem 58: $393-402$

16. Grigoriadis AE, Heersche JN, Aubin JE (1988) Differentiation of muscle, fat, cartilage, and bone from progenitor cells present in a bone-derived clonal cell population: effect of dexamethasone. J Cell Biol 106: 2139-2151. [Crossref]

17. [Crossref] Hardy CL (1995) The homing of hematopoietic stem cells to the bone marrow. Am J Med Sci 309: 260-266.

18. Haynesworth SE, Baber MA, Caplan AI (1992) Cell surface antigens on human marrow-derived mesenchymal cells are detected by monoclonal antibodies. Bone 13: 69-80. [Crossref]

19. Horwitz EM, Prockop DJ, Fitzpatrick LA, Koo WW, Gordon PL, et al. (1999) Transplantability and therapeutic effects of bone marrow-derived mesenchymal cells in children with osteogenesis imperfecta. Nat Med 5: 309-313. [Crossref]

20. Juan G, Darzynkiewicz Z (1998) Cell cycle analysis by flow and laser scanning cytometry. Cell Biol 1: 261-274

21. Keating A (2006) Mesenchymal stromal cells. Curr Opin Hematol 13: 419-425. [Crossref]

22. Al Kindi A, Ge Y, Shum-Tim D, Chiu RC (2008) Cellular cardiomyoplasty: routes of cell delivery and retention. Front Biosci 13: 2421-2434. [Crossref]

23. Li Y, Zhang C, Xiong F, Yu MJ, Peng FL, et al. (2008) Comparative study of mesenchymal stem cells from C57BL/10 and mdx mice. BMC Cell Biol 9: 24. [Crossref]

24. Minguell JJ, Conget P, Erices A (2000) Biology and clinical utilization of mesenchymal progenitor cells. Braz J Med Biol Res 33: 881-887. [Crossref]

25. Müller-Ehmsen J, Whittaker P, Kloner RA, Dow JS, Sakoda T, et al. (2002) Surviva and development of neonatal rat cardiomyocytes transplanted into adult myocardium. $J$ Mol Cell Cardiol 34: 107-116. [Crossref]

26. Beyer Nardi N, da Silva Meirelles L (2006) Mesenchymal stem cells: isolation, in vitro expansion and characterization. Handb Exp Pharmacol : 249-282. [Crossref]

27. Olivares EL, Ribeiro VP, Werneck de Castro JP, Ribeiro KC, Mattos EC, et al. (2004) Bone marrow stromal cells improve cardiac performance in healed infarcted rat hearts. Am J Physiol Heart Circ Physiol 287: H464-470. [Crossref]

28. Ortiz LA, Gambelli F, McBride C, Gaupp D, Baddoo M, et al. (2003) Mesenchyma stem cell engraftment in lung is enhanced in response to bleomycin exposure and ameliorates its fibrotic effects. Proc Natl Acad Sci U S A 100: 8407-8411. [Crossref]

29. Reading L, Still K, Bishop N, Scutt A. Peripheral blood as an alternative source of mesenchymal stem cells. Bone 2000; 26: Suppl

30. Tropel P, Noël D, Platet N, Legrand P, Benabid AL, et al. (2004) Isolation and characterisation of mesenchymal stem cells from adult mouse bone marrow. Exp Cell Res 295: 395-406. [Crossref]

31. Warejcka DJ, Harvey R, Taylor BJ, Young HE, Lucas PA (1996) A population of cells isolated from rat heart capable of differentiating into several mesodermal phenotypes. $J$ Surg Res 62: 233-242. [Crossref]

32. Xiao QZ, Li HW, Wen GM, Liu JB, Zhang XM, et al. (2004) Study on the biologica characteristics of rat bone marrow mesenchymal stem cells. Zhongguo Bingli Shengli Zazhi 3: 289-294

33. Zhao DC, Lei JX, Chen R, Yu WH, Zhang XM, et al. (2005) Bone marrow - derived mesenchymal stem cells protect against experimental liver fibrosis in rats. World $J$ Gastroenterol 22: 3431-3440

34. Zohar R, Sodek J, McCulloch CA (1997) Characterization of stromal progenitor cells enriched by flow cytometry. Blood 90: 3471-3481. [Crossref]

35. V.E. Kalodimou (2013), Basic Principles in Flow Cytometry, Bethesda Md.: AABB Press.

36. V.E. Kalodimou (2015), A Handbook to Mesenchymal Stem Cells in Regenerative Medicine, Specg. Co.

Copyright: (C)2016 Kalodimou VE. This is an open-access article distributed under the terms of the Creative Commons Attribution License, which permits unrestricted use, distribution, and reproduction in any medium, provided the original author and source are credited. 